\title{
Primary balloon dilatation of coarctation of the aorta in neonates
}

\author{
Andrew N Redington, Phillip Booth, Darryl F Shore, Michael L Rigby
}

Department of Paediatric Cardiology, Brompton Hospital, London

A N Redington

P Booth

D F Shore

M L Rigby

Correspondence to Dr Andrew N Redington, Department of Paediatric Cardiology, Brompton Hospital, Fulham Road, London SW3 6HP.

Accepted for publication 24 May 1990

\begin{abstract}
Primary balloon dilatation of coarctation of the aorta was attempted in 10 consecutive neonates (age range 2-23 days). The coarctation site was crossed and the balloon inflated in all but one patient. In two patients with associated severe isthmal hypoplasia there was no change in the gradient after dilatation. In the remainder, the residual gradients were trivial and angiography showed complete relief of coarctation.

Severe recoarctation developed 5-12 weeks after dilatation in five patients, each considered to have had an excellent initial result. The coarctation was rapidly progressive in three patients in whom Doppler studies within two weeks of the development of recoarctation had shown no significant gradient. In the other two patients progressive restenosis was charted by Doppler examinations over the course of 6-8 weeks. Three patients had a second, initially successful, dilatation procedure. One patient remained well with no residual gradient 18 weeks later. Stenosis recurred within eight weeks in the other two, and both have undergone successful surgical repair.

Balloon dilatation of a native coarctation of the aorta gave excellent immediate results in most neonates. Severe isthmal hypoplasia is, however, a contraindication to balloon dilatation and early restenosis is an important problem. These results do not support the continued use of primary balloon dilatation of coarctation of the aorta in neonates.
\end{abstract}

Balloon dilatation of the aorta is the chosen treatment for recoarctation of the aorta after surgical repair. ${ }^{1-3}$ Its efficacy in the treatment of native coarctation is less well established. Variable success has been reported in infants and young children undergoing the procedure, ${ }^{4-6}$ but follow up is necessarily short, and questions regarding the long term development of aortic aneurysm remain unanswered. To date there are only scattered reports of primary balloon dilatation of coarctation of the aorta in neonates presenting with severe coarctation in the first four weeks of life. ${ }^{7-9}$

We describe our early experience with this group of patients. Follow up is short, but early restenosis after complete early relief was common.
Patients and methods

Since December 1988, 10 consecutive neonates presenting to the Brompton Hospital with unoperated coarctation of the aorta have undergone attempted balloon dilatation of coarctation of the aorta. The median age at presentation was 10 (range 2-23) days and the mean (SD) weight was $3.2(1 \cdot 2) \mathrm{kg}$. The table shows patient details and associated anomalies. One patient had complete transposition of the great arteries, four patients had a small perimembranous ventricular septal defect, and one patient had a large doubly committed juxta-arterial ventricular septal defect thought to be suitable for primary repair if balloon dilatation were successful. At presentation none of the patients had femoral pulses. Three patients presented with cardiovascular collapse requiring resuscitation and prostaglandin infusion; the remainder presented with tachypnoea and poor feeding. The full sequential diagnosis was established by cross sectional echocardiography in each patient. The maximum velocity across the coarctation site was recorded by continuous wave Doppler measurements and the peak instantaneous pressure gradient was calculated by the modified Bernoulli equation. These measurements were repeated 48 hours after the procedure and every two weeks during follow up.

Informed, written consent for cardiac catheterisation and possible balloon dilatation was obtained from the parents in each case. Cardiac catheterisation was performed with sedation and local anaesthesia in two patients and with general anaesthesia in the remainder. We used a percutaneous retrograde femoral arterial approach in all patients. In eight of the patients a size 7 French valved introducer was inserted $1-2 \mathrm{~cm}$ into the femoral artery and stabilised by immediate passage of the angiographic catheter. This technique enables multiple catheter changes, including the balloon dilatation catheter, with slight blood loss and damage to the artery. In two of the smallest patients a size 5 French valved introducer was inserted initially and the balloon dilatation catheter was later introduced percutaneously. All patients were given a loading dose of $50 \mathrm{IU}$ of heparin $/ \mathrm{kg}$ body weight when the introducer was inserted.

A size 5 French multipurpose catheter was used to cross the coarctation site and in general this procedure was uncomplicated. The pressure gradients before dilatation were thus recorded as the difference between the peak systolic pressure in the descending aorta before and the peak systolic pressure in the 


\begin{tabular}{|c|c|c|c|c|c|c|c|c|}
\hline $\begin{array}{l}\text { Case } \\
\text { no }\end{array}$ & $\begin{array}{l}\text { Age } \\
\text { (days) }\end{array}$ & Symptoms & Associated abnormalities & $\begin{array}{l}\text { Gradient } \\
\text { before } \\
\text { dilatation } \\
(\mathrm{mm} \mathrm{Hg})\end{array}$ & $\begin{array}{l}\text { Gradient } \\
\text { after } \\
\text { dilatation } \\
(\mathrm{mm} \mathrm{Hg})\end{array}$ & $\begin{array}{l}\text { Balloon } \\
(\mathrm{mm})\end{array}$ & $\begin{array}{l}\text { Weight } \\
\text { (kg) }\end{array}$ & Outcome/follow up \\
\hline 1 & 5 & $\begin{array}{l}\text { Cyanosis, } \\
\text { tachypnoea }\end{array}$ & $\begin{array}{l}\text { Transposition of great arteries; } \\
\text { persistent ductus arteriosus }\end{array}$ & 38 & 0 & 8 & $3 \cdot 0$ & $\begin{array}{l}\text { Successful anatomical correction } \\
48 \text { hours after dilatation; } \\
\text { recoarctation at } 8 \mathrm{wk} \text {; surgical } \\
\text { repair }\end{array}$ \\
\hline 2 & 8 & Mild tachypnoea & None & 40 & 0 & 8 & 3.9 & $\begin{array}{l}\text { Recoarctation at } 5 \text { wk; repeat } \\
\text { dilatation at } 8 \text { wk; restenosis- } \\
\text { successful surgery }\end{array}$ \\
\hline 3 & 23 & $\begin{array}{l}\text { Poor feeding, } \\
\text { tachypnoea }\end{array}$ & $\begin{array}{l}\text { Small persistent ductus arteriosus; } \\
\text { bicuspid aortic valve }\end{array}$ & 38 & 8 & 8 & $3 \cdot 7$ & $\begin{array}{l}\text { Recoarctation at } 6 \text { wk; repeat } \\
\text { dilatation at } 9 \text { wk; restenosis- } \\
\text { successful surgery }\end{array}$ \\
\hline 4 & 2 & $\begin{array}{l}\text { Collapse-on } \\
\text { prostaglandin } \mathrm{E}_{2}\end{array}$ & $\begin{array}{l}\text { Anomalous origin of left SCA; } \\
\text { moderate perimembranous VSD }\end{array}$ & - & - & - & $2 \cdot 8$ & Unable to cross coarctation site \\
\hline 5 & 21 & Tachypnoea & Perimembranous VSD & 45 & 0 & 8 & $3 \cdot 1$ & $\begin{array}{l}\text { Follow-up } 37 \text { weeks: normal } \\
\text { femoral pulses and Doppler } \\
\text { echocardiography }\end{array}$ \\
\hline 6 & 9 & $\begin{array}{l}\text { Collapse—on } \\
\text { prostaglandin } E_{2}\end{array}$ & Persistent ductus arteriosus & 40 & 8 & 8 & $3 \cdot 4$ & $\begin{array}{l}\text { Gradual recoarctation; successful } \\
\text { surgery }\end{array}$ \\
\hline 7 & 3 & $\begin{array}{l}\text { Poor feeding, } \\
\text { tachypnoea }\end{array}$ & $\begin{array}{l}\text { Large doubly committed subarterial } \\
\text { VSD; isthmal hypoplasia }\end{array}$ & 16 & 24 & 8 & $4 \cdot 2$ & $\begin{array}{l}\text { Unsuccessful procedure; isthmal } \\
\text { dissection found at surgery; end- } \\
\text { to-end anastomosis + PA banding }\end{array}$ \\
\hline 8 & 12 & $\begin{array}{l}\text { Cyanosis, poor } \\
\text { feeding, pre-renal } \\
\text { failure }\end{array}$ & $\begin{array}{l}\text { Anopthalmia, musculoskeletal } \\
\text { abnormalities }\end{array}$ & 50 & 0 & 6 & $2 \cdot 8$ & $\begin{array}{l}\text { Follow-up } 22 \text { weeks: normal } \\
\text { femoral pulses and Doppler }\end{array}$ \\
\hline 9 & 15 & $\begin{array}{l}\text { Tachypnoea, poor } \\
\text { feeding }\end{array}$ & Small perimembranous VSD & 16 & 4 & 8 & $3 \cdot 1$ & $\begin{array}{l}\text { Gradual recoarctation; } \\
\text { successful } 2 \text { nd balloon } \\
\text { dilatation; follow up } 22 \text { weeks }\end{array}$ \\
\hline 10 & 3 & $\begin{array}{l}\text { Collapse—on } \\
\text { prostaglandin } \mathrm{E}_{2}\end{array}$ & $\begin{array}{l}\text { Isthmal hypoplasia; } \\
\text { perimembranous VSD; persistent } \\
\text { ductus arteriosus }\end{array}$ & 28 & 28 & 6 & 3.6 & $\begin{array}{l}\text { Referred for surgery; } \\
\text { uneventful recovery }\end{array}$ \\
\hline
\end{tabular}

PA, pulmonary artery; SCA, subbclavian artery; VSD, ventricular septal defect.

ascending aorta after passage of the catheter through the coarctation site before angiography. In one patient it was impossible to cross the coarctation site because the catheter persistently followed the course of an anomalous right subclavian artery that arose from the descending aorta close to the site of coarctation. Angiography also showed a tortuous and hypoplastic aortic arch and isthmus.

After aortography the balloon catheter was passed over an exchange guidewire left in the ascending aorta. We used a balloon the same size as (or a little smaller than) the diameter of the aorta at the diaphragm measured from the cross sectional echocardiogram (table). ${ }^{10}$ All balloons were carried on size 5 French catheters and were $15 \mathrm{~mm}$ long. After inflation to between four and eight atmospheres the balloon catheter was deflated and withdrawn, to leave the exchange wire in the ascending aorta. The size 5 French multipurpose catheter was then reinserted over the guidewire to enable repeat angiography and measurement of the pressure gradient on withdrawal.

All patients continued to be given a heparin infusion ( $400 \mathrm{IU} / \mathrm{kg} / 24 \mathrm{~h}$ ) for 24 hours after the procedure. One patient received an additional bolus of streptokinase and subsequent infusion because his leg was persistently pale and pulseless.

\section{Results}

In all patients severe preductal coarctation of the aorta was confirmed by aortography. The mean procedure time for the group was 68 minutes (range 33-118). In one patient it was impossible to cross the site of coarctation with the balloon catheter (see patients and methods).

The table shows the peak to peak systolic gradients measured before and after balloon dilatation in each patient. The mean (SD) systolic gradient before dilatation in the nine patients in whom balloon dilatation was attempted was 33 (13) $\mathrm{mm} \mathrm{Hg}$, falling to 7 (8) mm Hg ( $\mathrm{p}<0.001$, Student's $t$ test) after dilatation. Patient 1 underwent successful anatomical correction of transposition of the great arteries $\mathbf{4 8}$ hours after the procedure.

In two patients the systolic gradient was unchanged after the procedure (see below for details). Selective ascending aortography after dilatation in the remainder showed excellent relief of coarctation in all, with no evidence of aneurysm formation. Minor irregularities of the vessel wall, particularly of the anterior surface of the aorta seen in lateral projection, were common (fig 1).

The peak instantaneous systolic gradient measured by Doppler aortography across the coarctation was recorded 48 hours after the procedure and was similar to the immediate post-dilatation gradients measured on catheter withdrawal (fig 2). In two patients (cases 7 and 10) there was no change in gradient after balloon dilatation. In patient 7 , despite multiple balloon inflations with pressures $>6$ atmospheres, there was a persistent waist at the site of coarctation and no reduction in the gradient. This patient subsequently underwent surgical repair. At operation there was a severe dissection of the aortic isthmus with tears in the media and near rupture of the isthmus close to the coarctation site. Resection of the isthmus with an end-to-end anastomosis was performed. Subsequent recovery was uncomplicated. Review of the angiograms of this patient showed that the diameter of the balloon was $1 \mathrm{~mm}$ less than the diameter of the descending aorta at the diaphragm but $2 \mathrm{~mm}$ larger than at the hypoplastic isthmus. In the second patient there was a long tubular isthmal hypoplasia as well as discrete juxtaductal coarctation. The balloon diameter selected in this 
Figure 1 Angiograms of the ascending aorta recorded before (left) and after (right) balloon dilatation of a coarctation.

irregularities of the aortic wall in both left anterior oblique $(A)$ and lateral (B) angiographic projections. There are minor
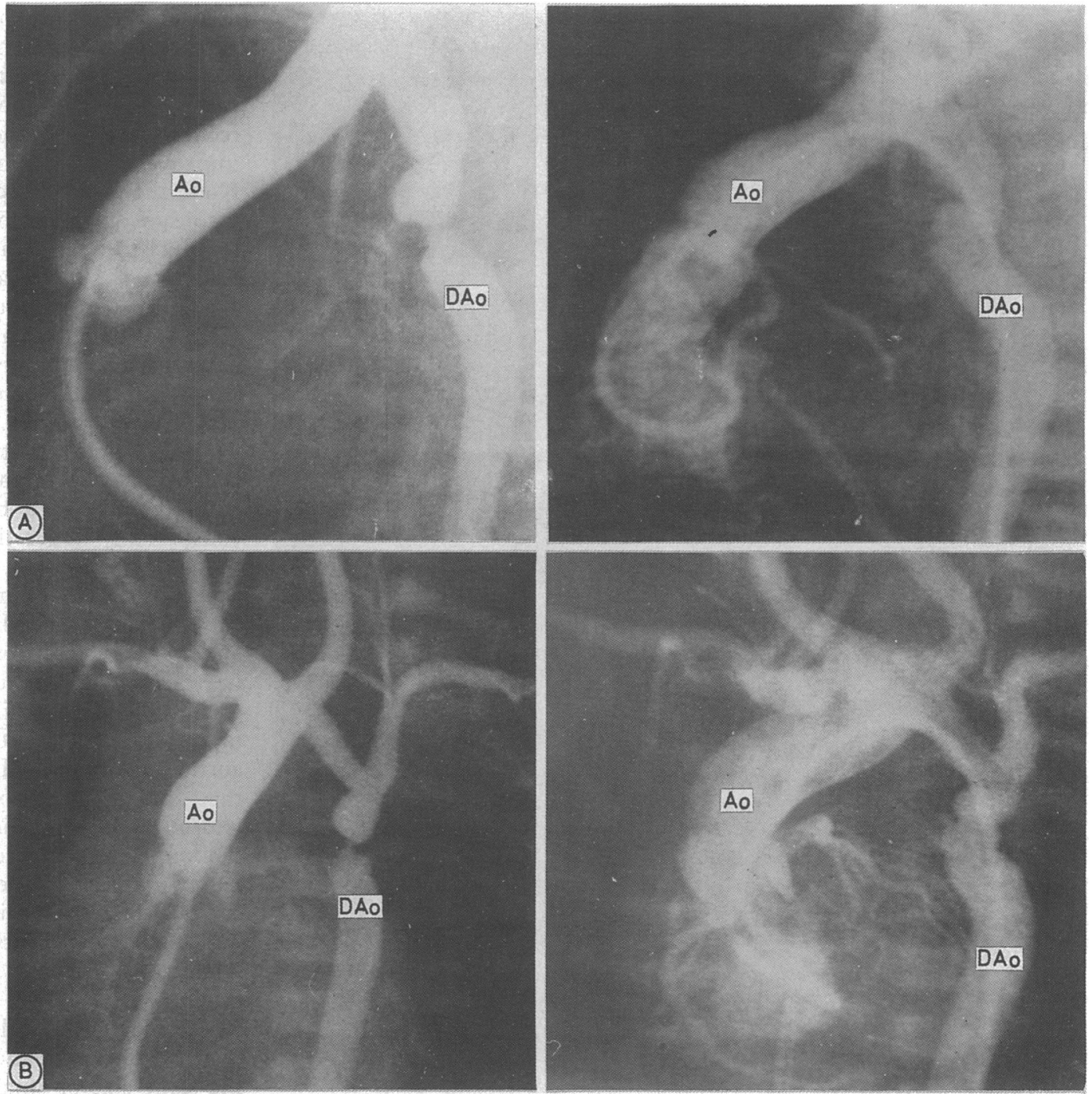

Figure 2 Continuous wave Doppler recordings of flow in the descending aorta before $(A)$ and after aorta before $(A)$ and after
$(B)$ balloon dilatation of coarctation of the aorta in patient 2. The pre-

dilatation recording shows the typical appearances of severe coarctation, with a prolonged diastolic

gradient. The appearances after aortoplasty are normal.

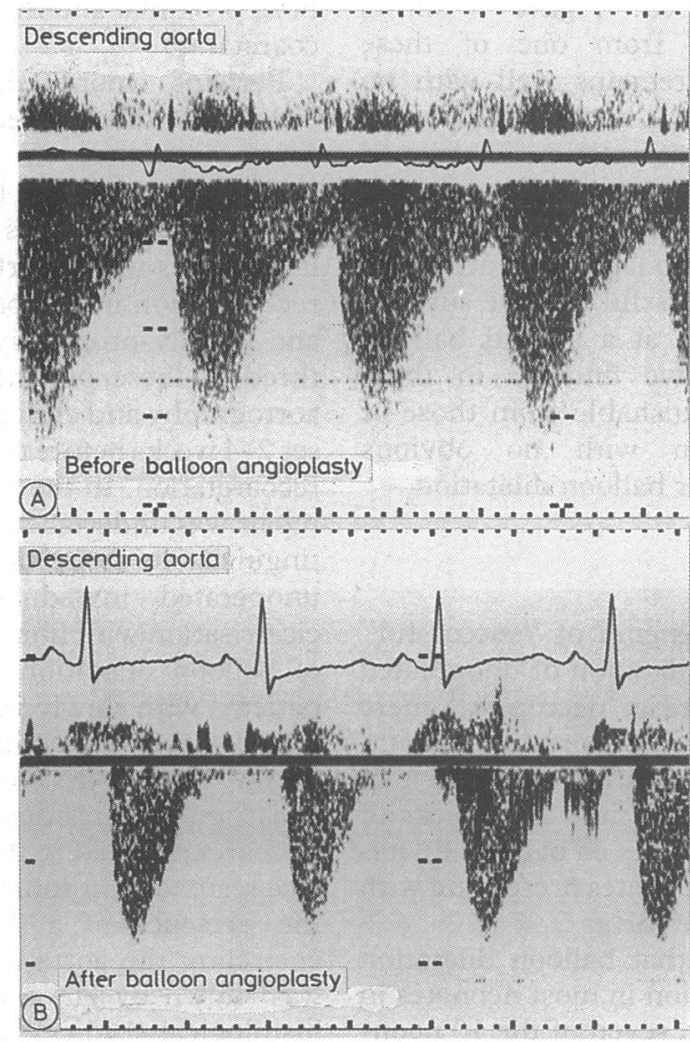

patient was chosen so that it did not exceed the diameter of the narrowed isthmus. Angiography after balloon dilatation demonstrated improvement in the appearances at the coarctation site, but the gradient across the isthmus was unchanged. This patient has also made an uncomplicated recovery after surgery.

Only two of the remaining seven patients were symptom free 22 and 37 weeks after the procedure. Both had excellent femoral pulses and no significant residual systolic gradient measured by continuous wave Doppler. There was severe recoarctation in five of the patients. All of these patients had excellent initial relief of the coarctation with no significant residual gradient after balloon dilatation. In three of the patients, restenosis was rapid and severe five, six, and eight weeks after dilatation (see table). Clinical studies and Doppler aortography were normal two weeks to four weeks before the discovery of recoarctation in these patients. None of them had femoral pulses and Dopplerdetected systolic gradients were 50,64, and $90 \mathrm{~mm} \mathrm{Hg}$ respectively.

In two further patients restenosis was slower and more progressive over $6-8$ weeks.

Three of these patients underwent a second balloon dilatation procedure and in all of them 


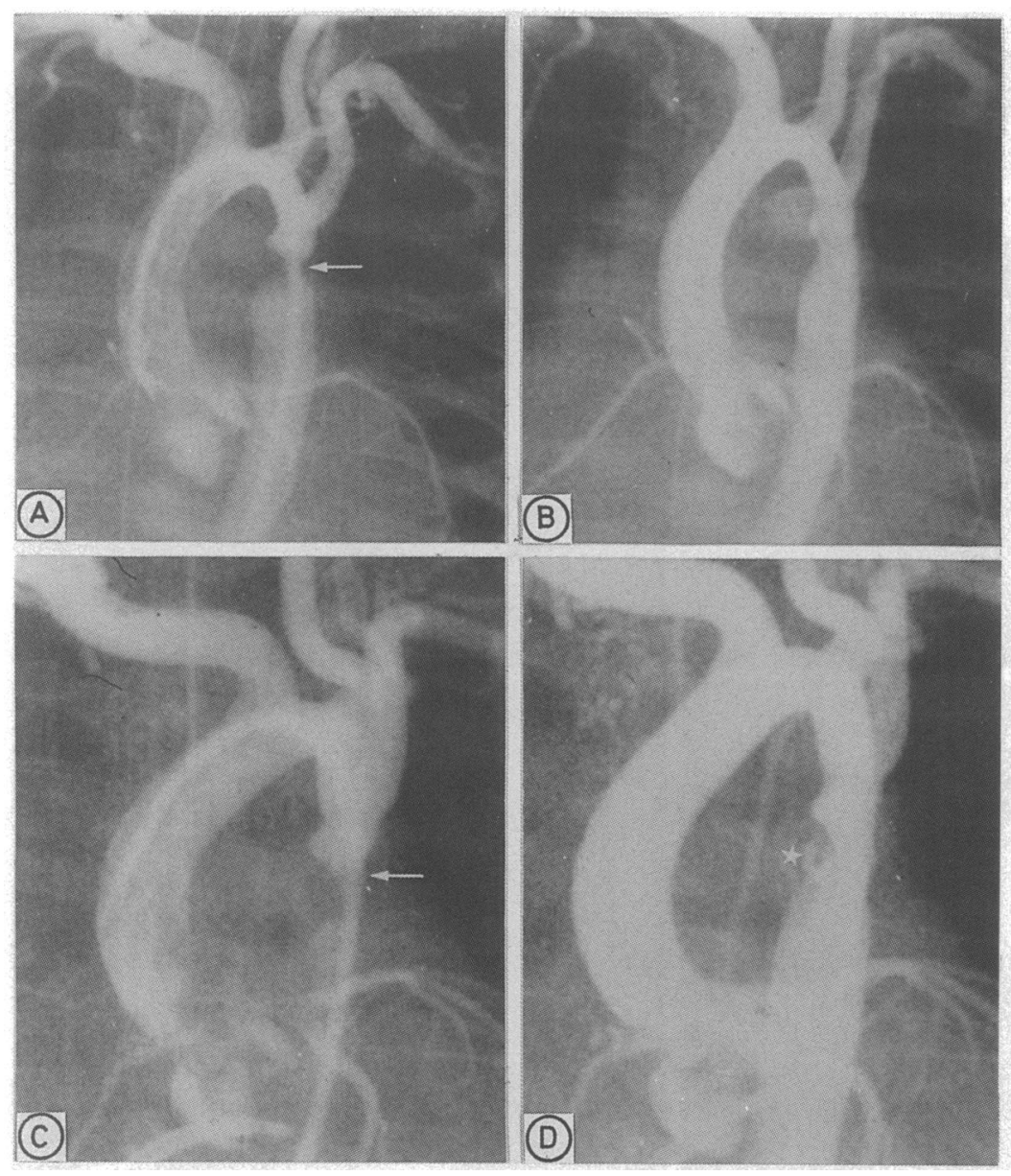

Figure 3 Serial left anterior oblique aortograms from patient 6. The top two panels show the appearances at original presentation (left) and the immediate result after balloon dilatation (right). Recoarctation occurred 6 weeks later (bottom left) and was successfully redilated (bottom right). A small intimal flap (*) was seen. Recoarctation occurred 8 weeks later and surgery was successful. ates in our study had only trivial residual gradients and excellent angiographic appearances immediately after the procedure. We believe that it is not possible to make any technical or methodological changes to improve the initial result in these patients. None the less, the results for the group as a whole are disapponting. There were three early failures. In one it was impossible to cross the coarctation site because the left subclavian artery arose anomalously from the descending aorta and there was a tortuous aortic arch and isthmus. The other two early failures were in patients with moderately severe tubular hypoplasia of the isthmus. Severe dissection of the isthmus was found at subsequent operation in one of them. This almost certainly resulted from the use of a balloon with a diameter considerably larger than that of the isthmus, though smaller than that of the descending aorta at the diaphragm. A different mechanism was invoked in an earlier case when a dissecting aneurysm of the aortic arch was found at necropsy in a one day old child who had undergone balloon dilatation for severe coarctation and subsequently died during open chest aortic valvotomy. ${ }^{12}$ These workers suggested that straightening of the balloon catheter within the hypoplastic arch explained the dissection that had occurred proximal to the narrowest part of the arch. Two conclusions can be drawn from this case and the experience with our two patients. First, we suggest that appreciable isthmal hypoplasia is a contraindication to balloon dilatation and secondly, while selection of balloon diameter according to the recommendations of Rao et al (that is, the same size or smaller than the descending aorta at the diaphragm $)^{10}$ is usually appropriate, care should be taken to avoid using a balloon with a bigger diameter than that of the aorta both proximal and distal to the site of discrete coarctation.

Perhaps more disappointing was the occurrence of early recoarctation in five of the seven neonates in whom an excellent immediate result had been obtained. Late restenosis several months after balloon aortoplasty in neonates was reported by others, ${ }^{413}$ but the recoarctation in our patients was much earlier and rapidly progressive in three of them. All three of these patients had normal Doppler aortography and clinically normal femoral pulses $2-4$ weeks before they presented with severe recoarctation. In the patients in whom surgical repair was undertaken, the findings were indistinguishable from the usual appearances of unoperated juxtaductal coarctation. While cicatrisation with fibrosis after the local trauma of balloon dilatation may be invoked in the patients with slowly progressive recoarctation, a more likely explanation, particularly in view of the time course of recoarctation, is that constriction of residual ductal tissue at the site of coarctation led to the more rapidly progressive restenosis in some of the patients. Indeed, the presence of a "sling" of ductal tissue encircling the aorta at the site of coarctation was shown by Ho and Anderson by detailed histological studies ${ }^{14}$ and this mechanism has
Our results showed that balloon dilatation relieved severe coarctation in most neonates in whom it was attempted; seven of the 10 neon- 
been invoked as a cause of early recoarctation after surgical repair. It must be more likely after balloon dilatation when the ductal tissue is neither incised nor removed.

Whatever the mechanism of restenosis, it is an important problem which taken with the early failure rate makes balloon dilatation unattractive in this group of patients. Particularly because surgical repair has a low mortality, ${ }^{15}$ and when the subclavian flap technique was used there is a low incidence of recoarctation. ${ }^{16}$ Thus, even in the absence of longer term follow up in the present series, we consider that surgical repair remains the best treatment for most neonates presenting with coarctation of the aorta.

Balloon dilatation of coarctation of the aorta can be performed in most neonates with a good early result. It is, however, unsuccessful and potentially dangerous in patients with associated isthmal hypoplasia. Furthermore, early restenosis is common, even when complete relief of coarctation is obtained. Though the technique may be useful when there are severe associated abnormalities, it cannot be recommended for general application in neonates with coarctation of the aorta.

1 Kan JS, White RI, Mitchell SE, Farmlett EJ, Donahoo JS, Gardner TJ. Treatment of restenosis of coarctation by percutaneous transluminal angiography. Circulation 1983;68:1087-94.

2 Saul JP, Keane JF, Fellows KE, Lock JE. Balloon dilation angioplasty of postoperative aortic obstructions. $A m J$ angioplasty of postoper

3 Rao PS. Which aortic coarctations should we balloon dilate? Am Heart J 1989;117:987-9.

4 Lababidi ZA, Daskalopoulos DA, Stoekle H. Transluminal balloon coarctation angioplasty: experience with 27 patients. Am J Cardiol 1984;54:1288-91.

5 Wren C, Peart I, Bain H, Hunter S. Balloon dilatation of unoperated aortic coarctation: immediate results and one year follow up. Br Heart $J$ 1987;58:369-73.

6 Morrow WR, Vick GW, Nihill MR, et al. Balloon dilation of unoperated coarctation of the aorta: short and intermediate-term results. J Am Coll Cardiol 1988;11:133-8.

7 Lock JE, Bass JL, Amplatz K, Fuhrman BP, CastenedaZuniga W. Balloon dilatation angioplasty of aortic coarcta-

tions in infants and children. Circulation 1983;68:109-16. Finley JP, Beaulieu RG, Nanton MA, Roy DL. Balloon catheter dilatation of coarctation of the aorta in young
infants. Br Heart $J 1983 ; 50: 411-5$. infants. Br Heart J 1983;50:411-5.

Attia IM, Lababidi ZA. Transumbilical balloon coarctation

angioplasty. Am Heart J 1988;116:1623-4.
10 Rao PS, Najiar HN, Mardini MK, Solymar L, Thapar MK. Balloon angioplasty for coarctation of the aorta: immediate and long-term results. Am Heart J 1988;115:657-65.

11 Sos T, Sniderman KW, Rettek-Sos B, et al. Percutaneous transluminal dilatation of coarctation of thoracic aorta post mortem. Lancet 1979;iii:970-1.

$12 \mathrm{Krabill} \mathrm{KA,} \mathrm{Bass} \mathrm{JL,} \mathrm{Lucas} \mathrm{RV,} \mathrm{et} \mathrm{al.} \mathrm{Dissecting} \mathrm{transverse}$ aortic arch aneurysm after percutaneous transluminal balloon dilation angioplasty for an aortic coarctation. Pediatr Cardiol 1987;8:39-42.

13 Suarez de Lezo J, Fernandez R, Sancho M, et al. Percutaneous transluminal angioplasty for aortic isthmic coarctation in infancy. Am J Cardiol 1984;54:1 147-9.

14 Ho SY, Anderson RH. Coarctation, tubular hypoplasia, and the ductus arteriosus. Histological study of 35 specimens. the ductus arteriosus. Histol

15 Kopf GS, Hellenbrand W, Kleinman C, Lister G, Talner N, Laks $H$. Repair of aortic coarctation in the first three months of life: immediate and long-term results. Ann Thorac Surg 1986;41:425-30.

16 Nair UR, Jones O, Walker DR. Surgical management of severe coarctation of the aorta in the first month of life. $J$ Thorac Cardiovasc Surg 1983;86:587-90.

Editorial. ST segment changes as a surrogate end point in coronary thrombolysis $W$ Stewart Hillis, $K J$ Hogg (August issue: volume 64: pages 111-2)-The authors have asked us to point out that their address should have read: Department of Medicine and Therapeutics, University of Glasgow, Stobhill General Hospital, Balornock Road, Glasgow G21 3UW. 